IP Periodica Polytechnica Civil Engineering

\author{
60(4), pp. 491 502 2016 \\ DOI: 10.3311/PPci.8159 \\ Creative Commons Attribution (1) \\ RESEARCH ARTICLE
}

\section{Experimental Evaluation of the Strength of Peat Stabilized with Hydrated Lime}

\author{
Mohammad Nikookar, Mahyar Arabani, Seyed Mohammad Mirmoa'zen, Mehdi \\ Karimi Pashaki
}

Received 15-04-2015, revised 03-09-2015, accepted 04-09-2015

\begin{abstract}
This study compares the effects of different hydrated lime contents and curing periods in peat stabilization using unconfined compressive strength (UCS) and consolidated-undrained triaxial $(C U)$ tests which constitutes the first comprehensive experimental study on peat in Iran. Since it includes a novelty comparison between these tests along with providing experimental data for both test types. For this purpose, lime contents of 3, 6, 9, 12 and 15\% were used with different curing periods of 7, 14, 28 and 90 days. The results obtained in these tests were then compared. In order to compare, for triaxial tests, a novelty value of equivalent unconfined strength, which is the strength in case of hypothetical zero confining pressure in a triaxial test, is introduced and calculated and then compared with UCS values. Results indicate that the equivalent unconfined strengths of CU tests are always lower than those of the UCS test which can be attributed to pore water pressure generation in $C U$ tests which can decrease the equivalent unconfined strength of soil. Moreover, while the undrained cohesive strength is half of the UCS value, the undrained cohesive strength is 0.35 times the equivalent unconfined strength for peat. Such comparison between UCS test, which is quite common and easily conductible, and triaxial test, which provides the most comprehensive data in soil mechanics, could lead to credible results which can be widely applicable in forest areas and regions with much vegetation which is the case in northern parts of Iran. Moreover, based on the comparison, the optimum lime content for peat stabilization in this study was obtained between nine and twelve percent.
\end{abstract}

\section{Keywords \\ Peat soil · Stabilization · Hydrated Lime - Triaxial test - Un- confined Compressive Strength}

\section{Mohammad Nikookar}

Department of Civil Engineering, University of Guilan, Rasht, I. R., Iran e-mail: nikookar2006@yahoo.com

\section{Mahyar Arabani}

Seyed Mohammad Mirmoa'zen

Mehdi Karimi Pashaki

Department of Civil Engineering, University of Guilan, Rasht, I. R., Iran

\section{Introduction}

A large number of projects are constructed in areas with dense vegetation which behooves the engineers to investigate the properties and texture of soil in such areas which mostly include peat [1]. Peat is formed through the decomposition of organic matters and plant residues under water for many years. Its components may vary according to location, origin fiber, temperature and humidity [2]. The organic matters are generally categorized into peat, Dy and Gyttja. Peat originates from plants and denotes the various stages in the humification process where the plant structure can still be discerned [3]. The presence of organic matters may affect the soil properties. Peat soil has very low strength with very high compressibility and creep potential [4]. Due to its special structure, peat soil has high capacity of holding water [5]. Its structure is very loose and includes large pores. Due to its high absorption of water, the bearing capacity and the density of peat soils are not of great significance [2]. In massive construction projects, especially those located in areas with soils containing a large portion of peat, removing and replacing the peat can be both costly and labor-intensive. Therefore, soil stabilization can be an important alternative method in such cases to improve the geotechnical properties. In general, there are four types of organic matters in peat soils and they are humic acids, fulvic acids, humin and yellow organic acids which means that peat soils are highly acidic. Huat in 2004 [2] stated that during chemical reactions initiated by stabilization, stabilizer materials such as lime or cement neutralize the acidity and through the cementation process initiated afterward, the strength properties of peat improve. Kazemian et al. in 2015 [6] showed that by adding cement, sodium silicate and kaolinite as binders, the void ratio and the coefficient of secondary compression of treated fibrous peat decrease. Kalantari and Prassad [7] in a study investigated the effect of three curing techniques of moist curing, air curing and moist curing with surcharge load on the strength of cement-treated peat. They indicated that the moist curing technique leads to lower strengths in comparison to adopting the other two curing techniques.

Stabilization by lime can be used for projects where high strength and high performance of materials are required [8]. Use 
Tab. 1. Basic properties of Kolou peat soil

\begin{tabular}{ccc}
\hline Parameters & Standard & Values \\
\hline Depth of Sampling $(\mathrm{cm})$ & - & $10-40$ \\
\hline Maximum Dry Density $\left(\mathrm{g} / \mathrm{cm}^{3}\right)$ & ASTM D 698-00 & 1.09 \\
\hline Optimum Moisture Content $(\%)$ & ASTM D 698-00 & 29 \\
\hline Liquid Limit (\%) & ASTM D 4318-00 & 71.8 \\
\hline Plastic Limit (\%) & ASTM D 4318-00 & 70.9 \\
\hline Organic Content (\%) & ASTM D2974-07a & 85 \\
\hline Specific Gravity & ASTM D 854-02 & 1.6 \\
\hline Natural Moisture Content (\%) & ASTM D 2216-98 & 400 \\
\hline Ash Content (\%) & ASTM D2974-07a & 14.9 \\
\hline Fiber Content (\%) & ASTM D 1997-91 & 75 \\
\hline pH & ASTM D 4972 -01 & 4.2 \\
\hline Color & (visual) & Dark \\
\hline Degree of Humification & Von Post System & H8
\end{tabular}

of lime for soil stabilization, by producing cohesion between the particles of the soil and making the flocculated particle structure, increases soil strength and maximum dry density along with decreasing optimum moisture content and plastic properties, namely liquid limit, and plastic limit and thus improves the behavior under deformation [9].

In a study by Yusof et al. [10] the effect of using hydrated lime on the compressive strength of peat was investigated. The results indicated an increase in the strength and stiffness of treated peat. Bredenberg et al. [11] stabilized two different types of peat soils by adding cement and lime. In this study, the effects of these additives on peat soils were investigated by consolidation and unconfined compressive strength tests. Results indicated that the effect of stabilization depends on the nature and the stress history of the soil. Hebib et al. [12] evaluated some properties of two types of lime-stabilized peats by conducting unconfined compressive strength, triaxial and consolidation tests. Results indicated improvement of strength and stability properties of peat soil with the addition of lime. Huat et al. [13] conducted a series of experiments including unconfined compressive strength and Atterberg limit tests on lime-stabilized peats with lime contents ranging from 5 to $25 \%$ from total weight of each sample. It was noticed that as lime content increased, maximum density and unconfined compressive strength increased as well and a decrease was observed in the Atterberg limits and optimum moisture content. Said and Taib [14] studied the effect of carbide lime in the stabilization of organic soils with carbide lime contents of 3, 6, 9 and $12 \%$ in three curing periods of 7, 14, 28 days with taking use of unconfined compressive strength and compaction tests. Results showed that with the increase in carbide lime content, maximum density and unconfined compressive strength increased along with a decrease in optimum moisture content. Throughout this study, it was inferred that, since the cementation process is gradual in nature, the unconfined compressive strengths of specimens treated with higher carbide lime contents along with longer curing periods were considerably higher.
Peat soils comprise a large portion of the soils found in the Northern parts of Iran, especially in Guilan province, located on the south west coast of the Caspian Sea in which there are vast areas densely covered with trees and plants [1,4]. In the current study, the aim is to investigate the effects of hydrated lime content and curing period on the strength properties of hydrated lime-stabilized peat with unconfined compressive strength and $\mathrm{CU}$ triaxial tests through comparison between the two test type results which can yield useful and easily applicable results for the projects since UCS tests are widely used in projects while the triaxial tests are more credible and complicated.

\section{Experimental Procedures}

\subsection{Materials}

The peat soil for this laboratory investigation was gathered from woodlands of Kolou area in Talesh Mountains in northern Iran. In these areas, due to the highly humid climate and vast areas densely covered with trees and different types of plants, the peat layer can be quite thick followed by sedimentary layers [4]. After performing preliminary tests, some basic properties of the Kolou peat are presented in Table 1

In this study, ordinary hydrated lime with a unit weight of $2.4 \mathrm{~g} / \mathrm{cm}^{3}$ was used to stabilize the specimens. Table 2 shows the chemical compounds of hydrated lime.

Tab. 2. Chemical compounds of hydrated lime

\begin{tabular}{cc}
\hline $\mathrm{SiO}_{2}$ & $0.6 \%$ \\
\hline $\mathrm{CaO}$ & $68 \%$ \\
\hline $\mathrm{MgO}$ & $0.5 \%$ \\
\hline $\mathrm{Al}_{2} \mathrm{O}_{3}+\mathrm{Fe}_{2} \mathrm{O}_{3}$ & $1.3 \%$
\end{tabular}

\subsection{Samples Preparation}

Peat samples were taken from the depth of 10 to $40 \mathrm{~cm}$ from an all-year-long wet spot in Kolou and then transferred to the laboratory in thick plastic bags. The peat soil for laboratory tests was first passed through the sieve NO. 30 (0.733 mm opening) in order to remove roots, gravel and other coarse particles 

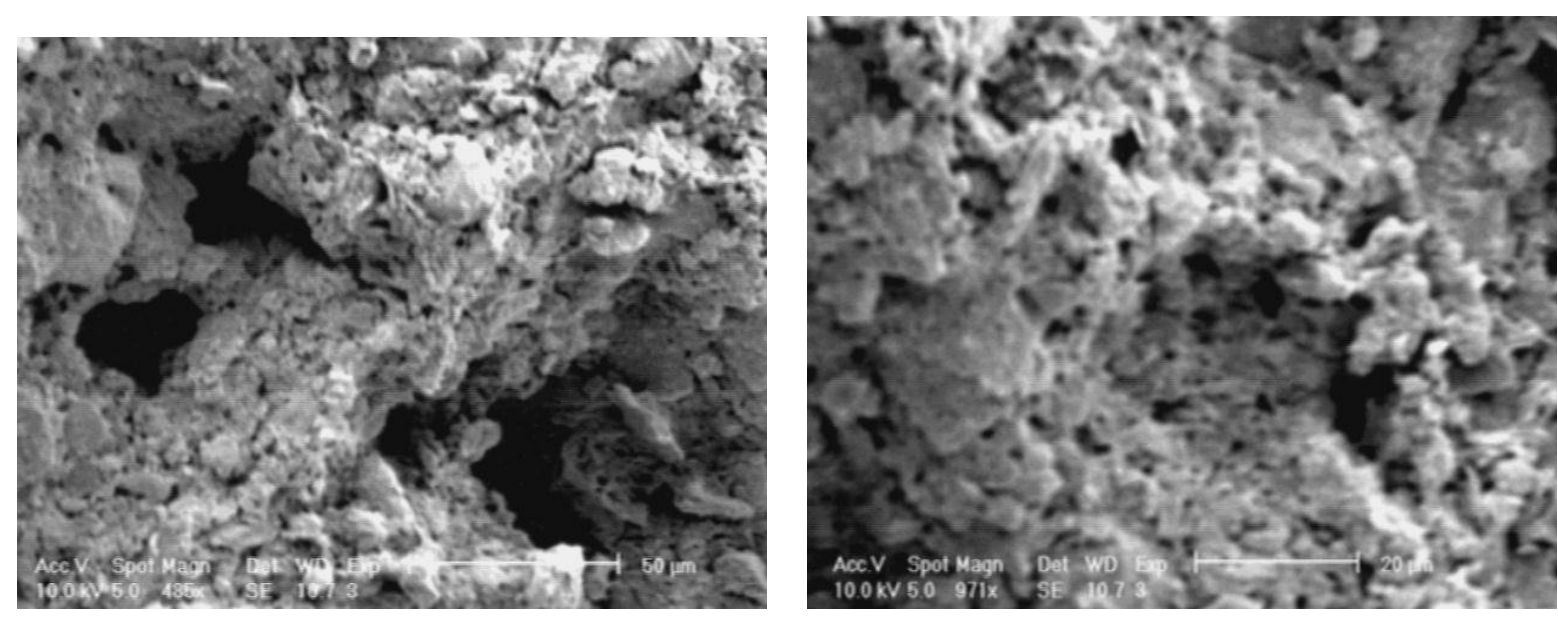

Fig. 1. SEM picture of untreated peat
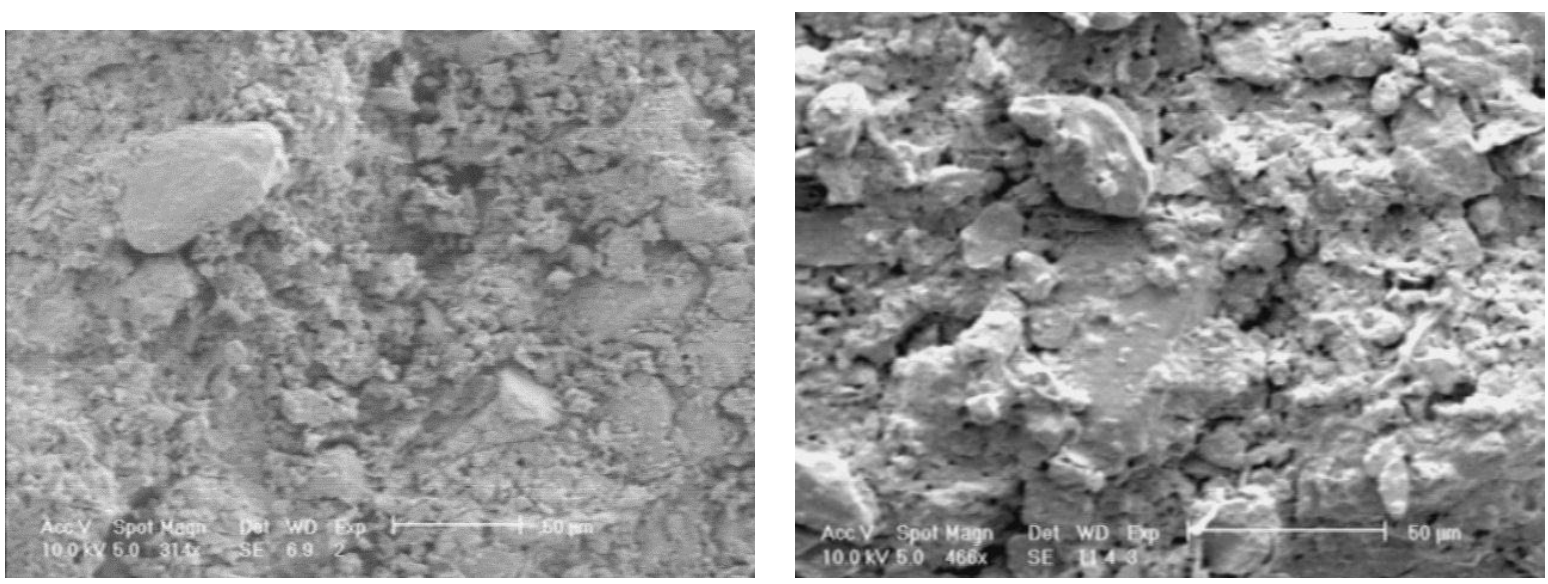

Fig. 2. SEM pictures of treated peats with $12 \%$ lime content after 7 days curing period (left) preserved in open bucket (right) preserved in desiccators
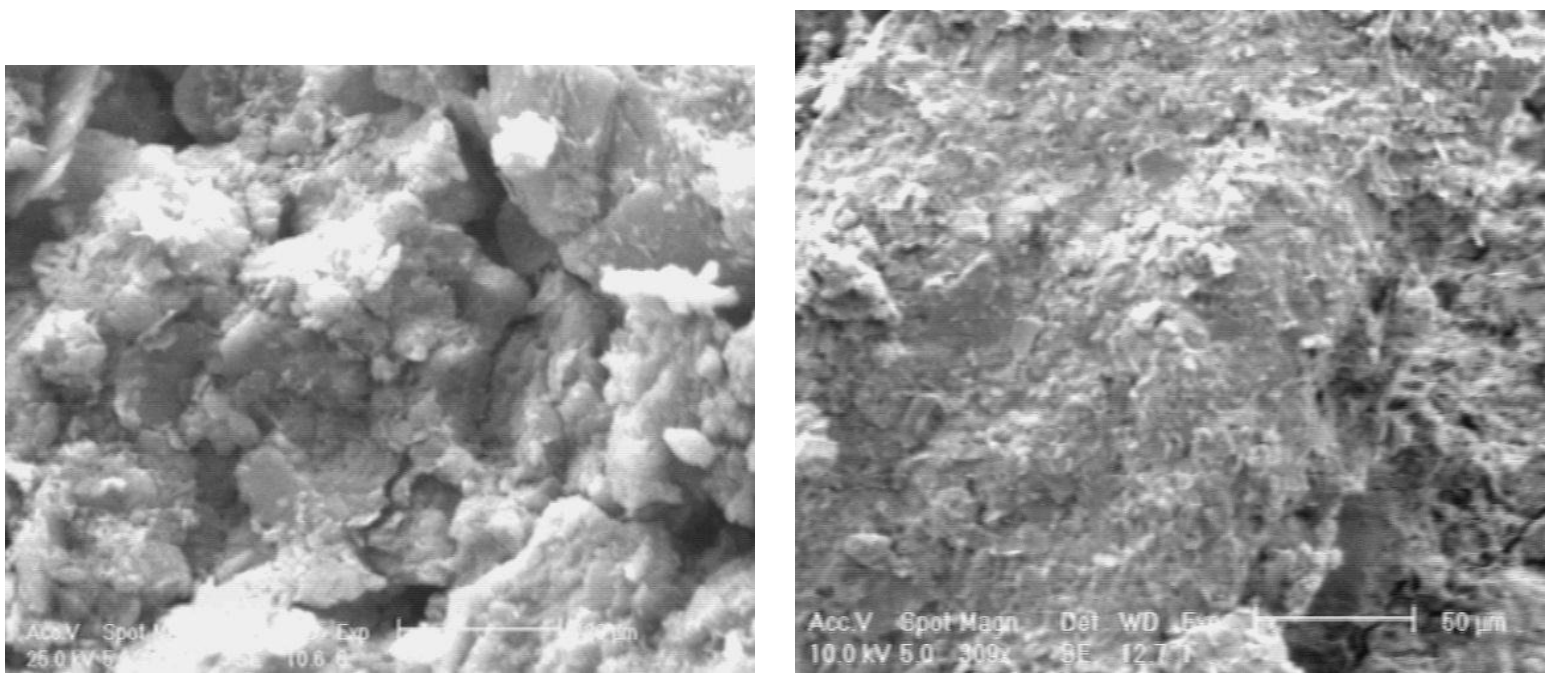

Fig. 3. SEM pictures of treated peats with $12 \%$ lime content in open bucket with two curing periods: (left) 28 days (right) 90 days 


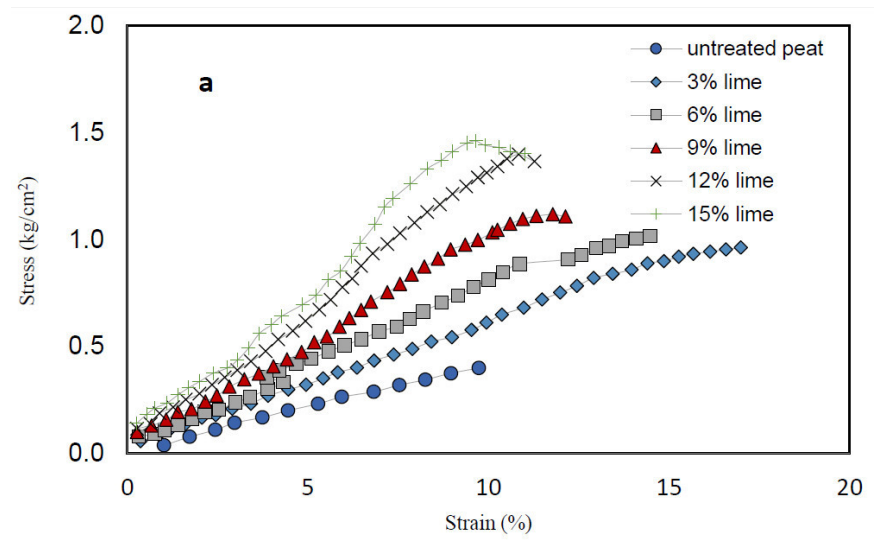

a) curing period of 7-days

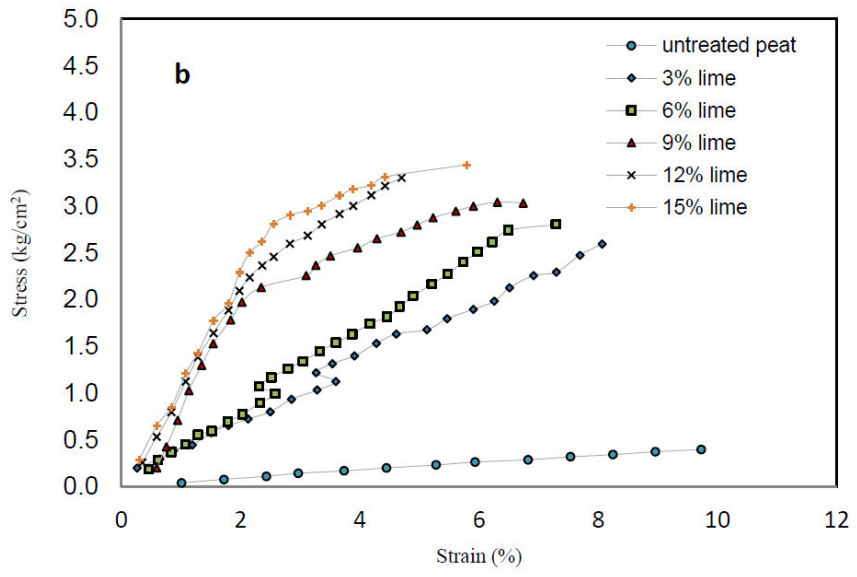

b) curing period of 28-days

Fig. 4. Unconfined compressive strength test results for Kolou peat samples treated with different lime contents

that peat normally carries in its natural state. Then the soil was retrieved from the mixture of water and soil passed through the sieve by getting dried up in the oven with temperatures no more than $44{ }^{\circ} \mathrm{C}$ to preserve the organic matters. The dried up soil was then broken into pieces and again passed through the sieve NO.30 to have smooth soil samples empty of coarse particles such as stones and debris. The treated specimens for the two test type contained lime contents of 3, 6, 9, 12 and $15 \%$. To prepare each of the treated samples, they were compacted in three layers in the mold with the maximum dry density and the optimum moisture content. The method adopted for sample preparation was the moist placement method. Based on the compaction test results, the values of the maximum dry density and the optimum moisture content for the untreated and the lime-treated peat samples were not significantly different, since compaction tests were performed instantly and enough time was not provided for the lime to react with the water. The values of the maximum dry density and the optimum moisture content for soil samples are presented in Table 3 . Moreover, the $\mathrm{pH}$ values for lime treated samples are shown in Table 4 and the Atterberg limits are presented in Table 5 to provide a better understanding of the changes in basic properties of untreated and lime treated peat.

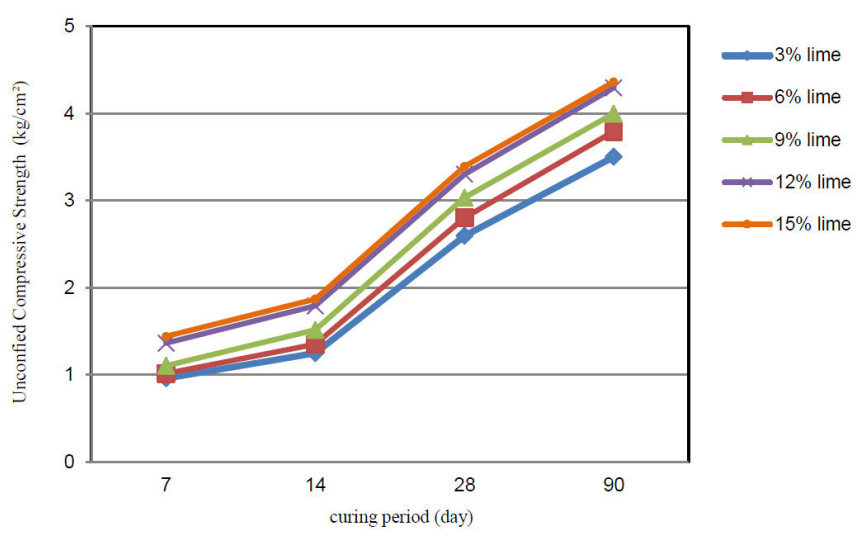

Fig. 5. Effect of curing period on the strength of the lime-treated samples

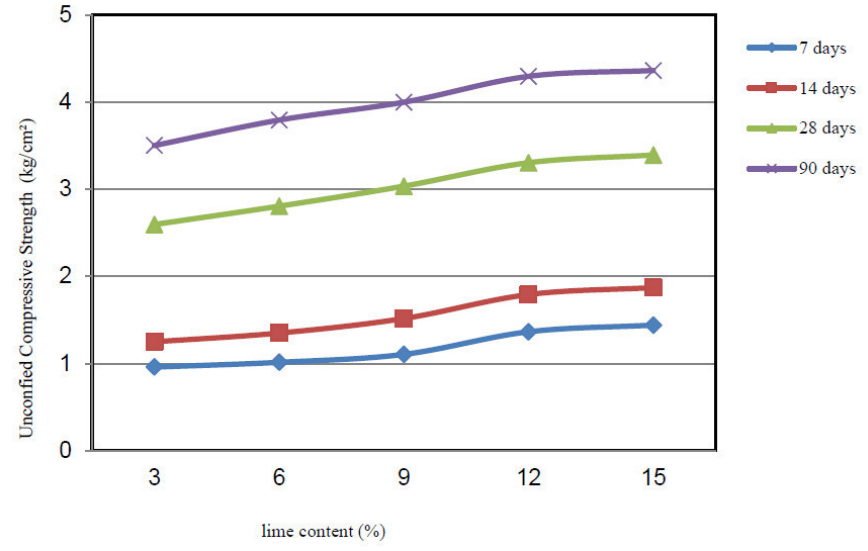

Fig. 6. Effect of lime contents on the unconfined compressive strength of specimens

In order to maintain the same preparation conditions, all samples with the same lime contents were prepared at the same time. UCS test samples, after being removed from the mold, were cured and preserved for 7, 14, 28, and 90 days in an open bucket and desiccators. Moreover, some of the specimens were first preserved and cured in desiccators for the first 7 days of the curing period before being exposed to the air for the rest of the curing process. CU triaxial test samples, after being removed from the mold, were thoroughly wrapped around in thin plastic covers with a height twice as high as the specimens, maintaining contact with the air only from the top and not either sides or bottom and were cured for 7, 14, 28 and 90 days, as well. The CU triaxial test samples were cured and preserved in the aforementioned way to ensure maximum closeness to the natural condition of a layer located at the surface, losing moisture from the top as a result of being exposed and rather not losing moisture from sides or bottom due to its contact with other moist layers. For the $\mathrm{CU}$ triaxial test, to speed up the saturation stage and to make the samples uniformly saturated filter paper drains were used before placing the membrane. All tests mentioned in this section were performed in laboratory conditions at the temperature of $25 \pm 2^{\circ} \mathrm{C}$. Different SEM pictures of states of untreated peat and 

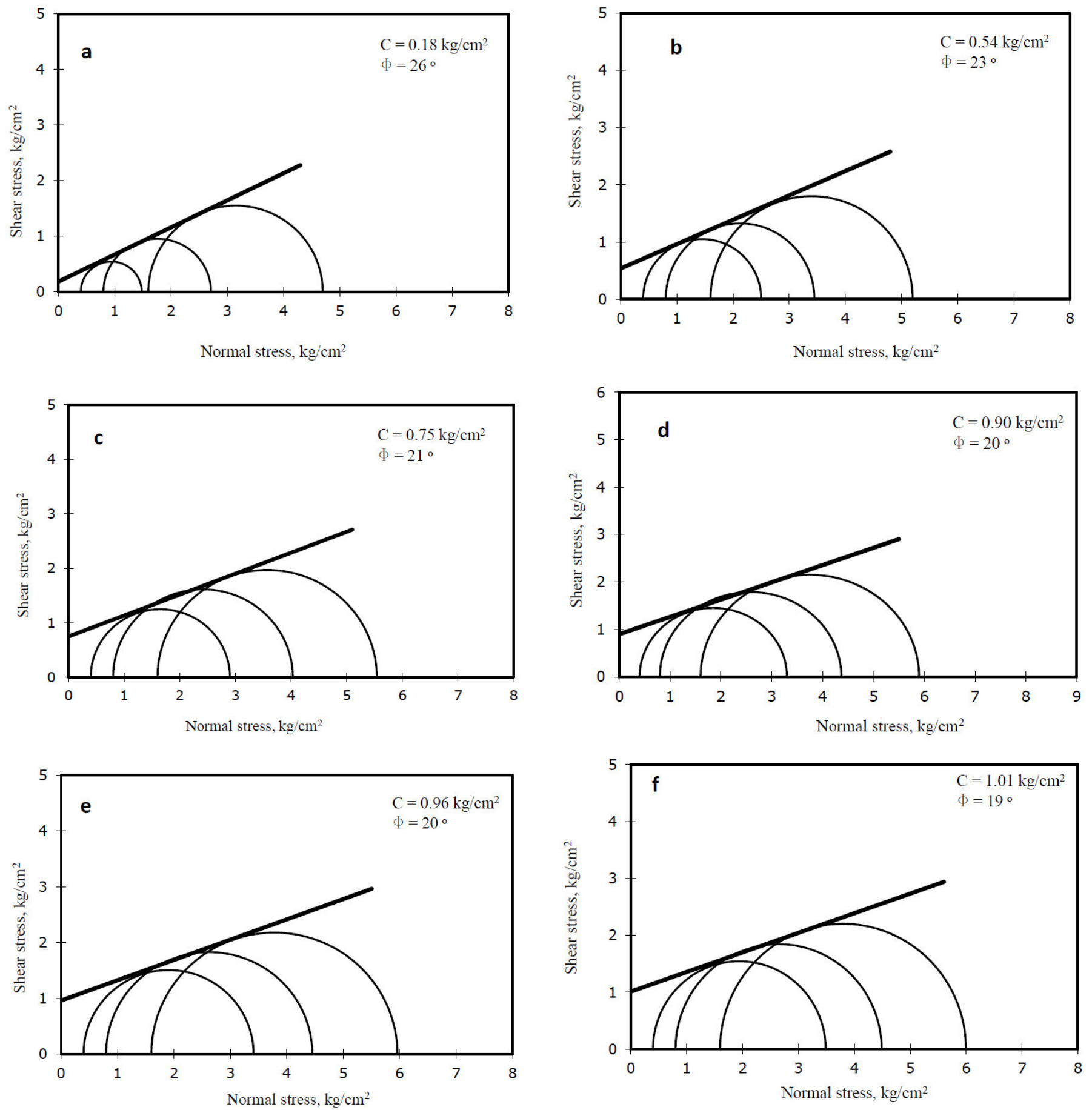

Fig. 7. The results of triaxial tests on 7-day samples by different lime content: a) no treatment, b) $3 \%$ lime content, c) $6 \%$ lime content, d) $9 \%$ lime con-

tent, e) $12 \%$ lime content, f) $15 \%$ lime content 

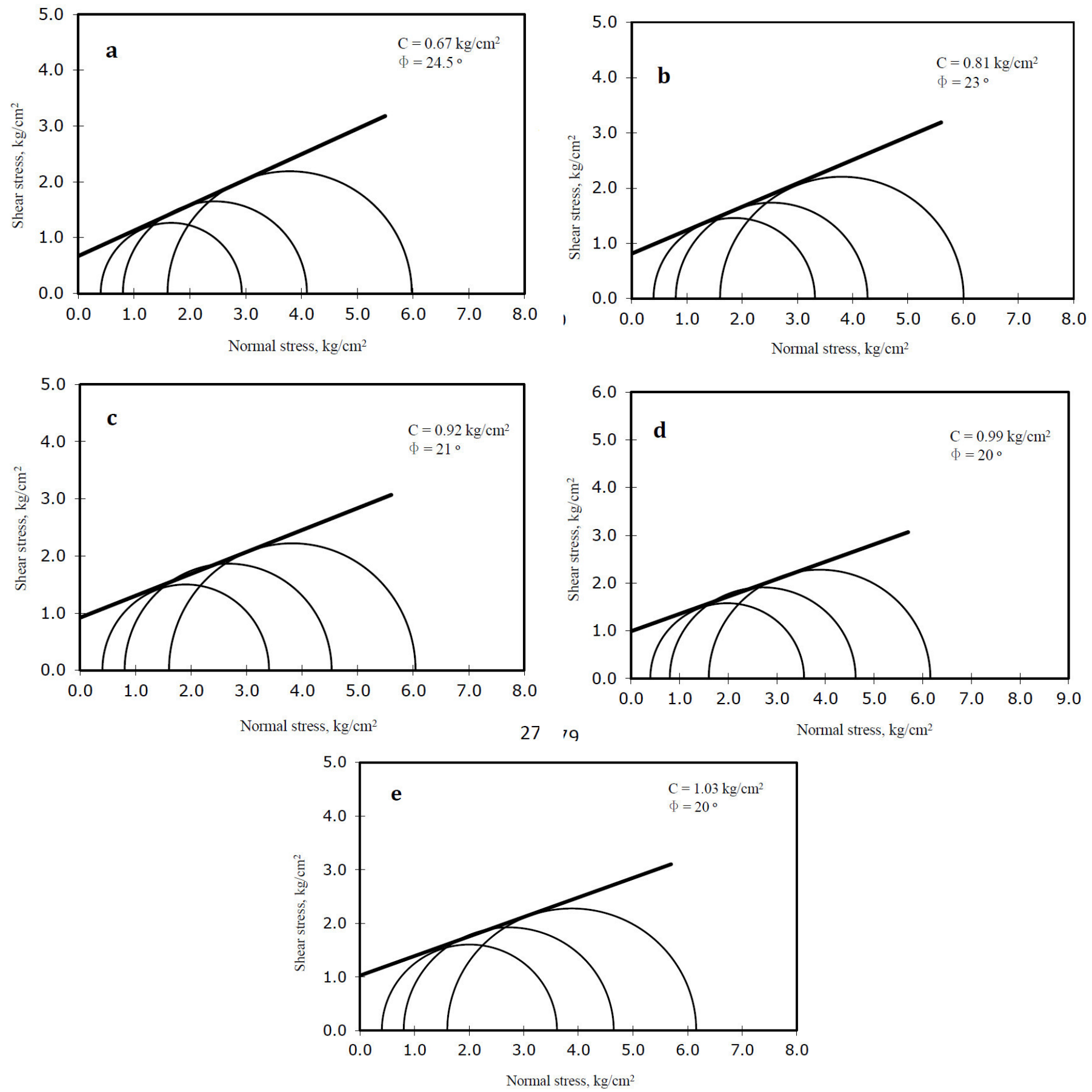

Fig. 8. The results of triaxial tests on 28-day samples by different lime concontent, e) $15 \%$ lime content tent: a) $3 \%$ lime content, b) $6 \%$ lime content, c) $9 \%$ lime content, d) $12 \%$ lime 

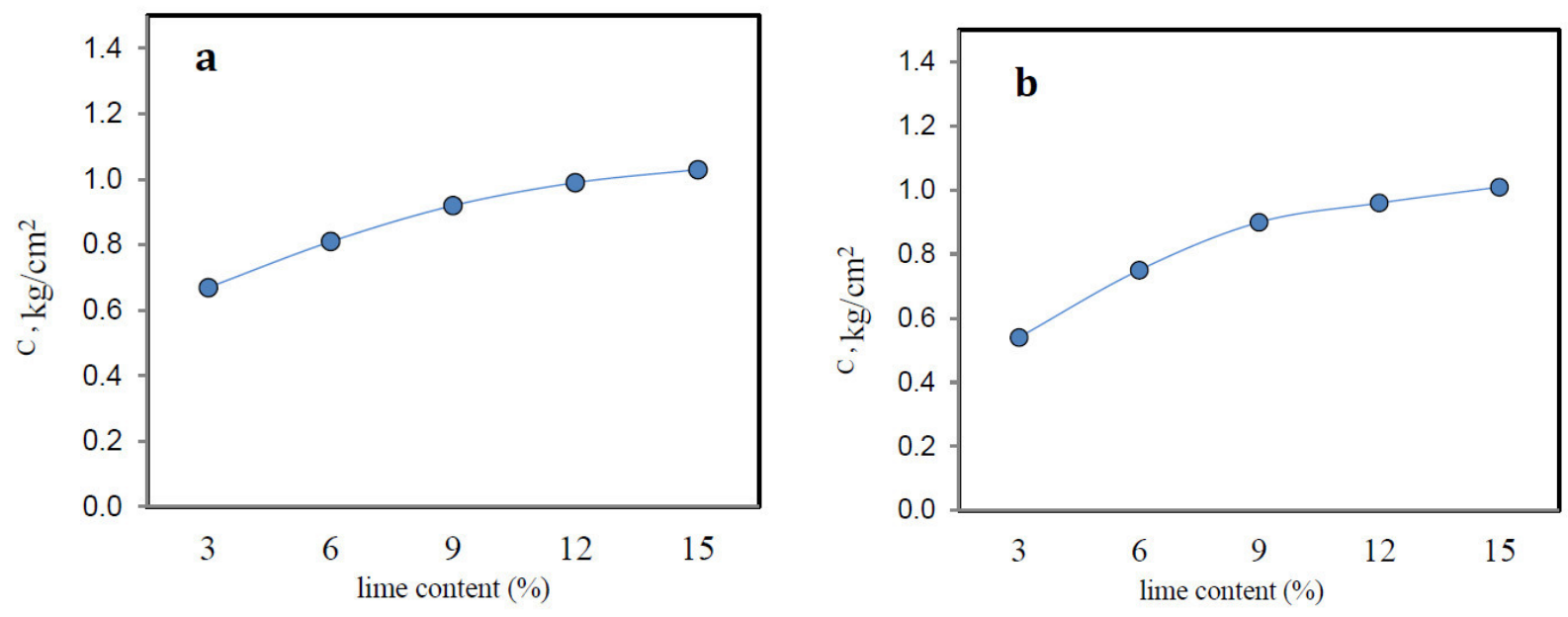

Fig. 9. Effect of different lime contents on the soil cohesion obtained from triaxial tests: a) 7-day curing period, b) 28-day curing period
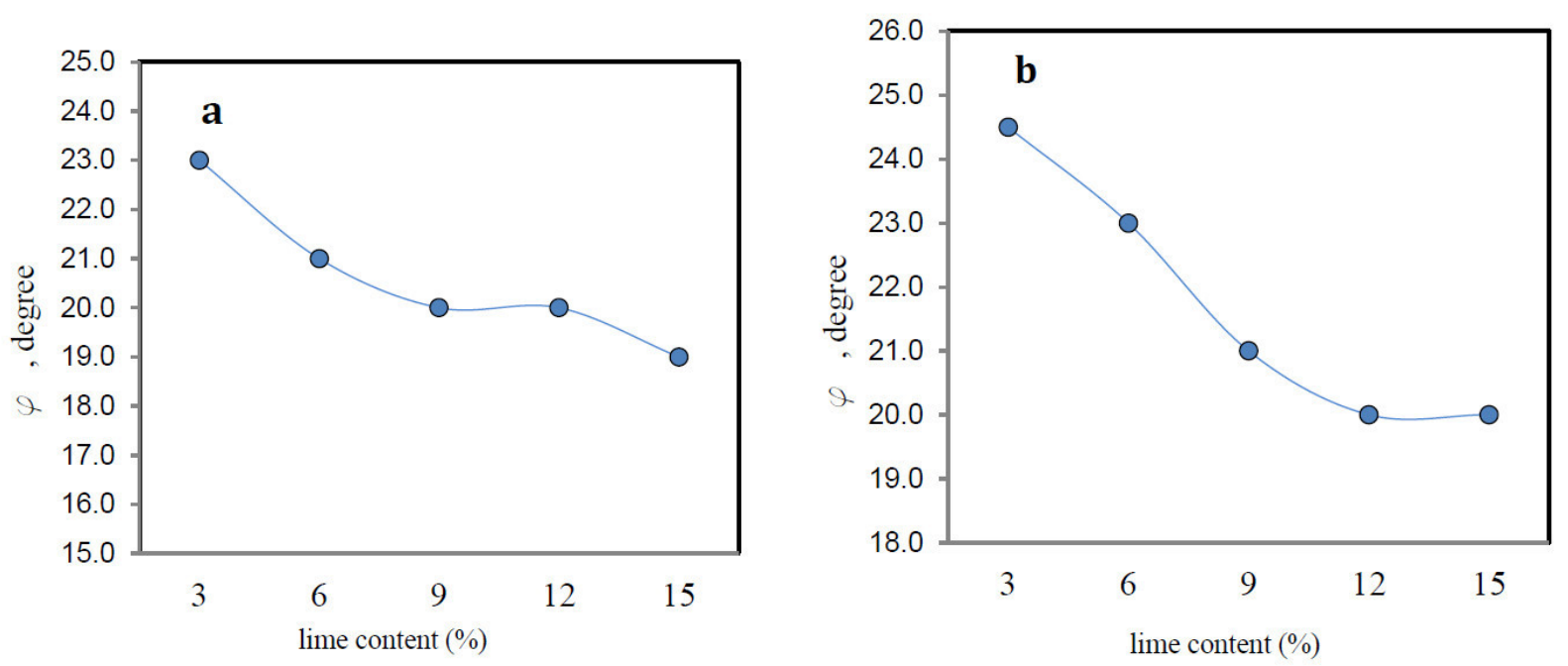

Fig. 10. Effect of different lime contents on the soil internal friction angle obtained from triaxial tests: a) 7-day curing period, b) 28-day curing period

treated peat using $12 \%$ lime content are shown in Figs. 1 to 3 . As indicated in Fig. 1. untreated peat has large pores and therefore a high potential for deformation. Fig. 2 shows stabilized peats under two different curing conditions, with and without the use of desiccators in the first seven days of the curing period for UCS samples; it's evident that sufficient moisture is required to initiate and maintain chemical reactions leading to cementation. By preserving the moisture content of the samples for the first 7 days with desiccators, more complex particles were created as a result of the completed chemical reactions in the presence of sufficient moisture. Continuing the curing process for the aforementioned days at the laboratory has a substantial effect on the stabilization. Interconnected structure in Fig. 3 indicates the full development of chemical reaction when there is 90 days curing period which results in more compacted structure [15].

Each test type was performed based on the corresponding ASTM standard. The unconfined compressive test was performed at an axial strain at a rate of $1 / 2$ to $2 \% / \mathrm{min}$. The strain rate in CU tests was applied at a constant rate of $0.2 \% / \mathrm{min}$ according to ASTM standard so uniform pore pressure is gener- ated throughout the specimen at failure. For CU triaxial tests, the time required for saturating the specimens grew fairly longer and greater back pressures were required as lime contents or the curing periods increased. The values of back pressures, cell pressures and time needed for saturation are given in Table 6 The back pressure for untreated soil sample applied $100 \mathrm{kPa}$ and, the back pressure increment used in this study was $25 \mathrm{kPa}$.

\section{Results and Discussion}

\subsection{Unconfined Compressive Strength Test}

The purpose of this test is to determine the undrained shear strength of saturated clays quickly. In the UCS test, no radial stress is applied to the sample $\left(\sigma_{3}=0\right)$. The axial load is increased rapidly until the soil sample fails, that is, it cannot support any additional load. The loading is applied quickly so that the pore water cannot drain from the soil; the sample is sheared at constant volume. The corresponding value of the stress is considered as the ultimate shear strength of the sample is equal to two times the undrained soil cohesion $\left(\mathrm{q}_{u=} 2 \mathrm{c}_{u}\right)$. The limestabilized specimens for the unconfined compressive strength 
Tab. 3. Maximum dry densities and optimum moisture content for samples

\begin{tabular}{ccccccc}
\hline Lime content $(\%)$ & $\mathbf{0}$ & $\mathbf{3}$ & $\mathbf{6}$ & $\mathbf{9}$ & $\mathbf{1 2}$ & $\mathbf{1 5}$ \\
\hline Maximum dry density $\left(\mathrm{g} / \mathrm{cm}^{3}\right)$ & 1.09 & 1.11 & 1.16 & 1.20 & 1.23 & 1.25 \\
\hline Optimum moisture content $(\%)$ & 29.2 & 28.6 & 27.9 & 27 & 25.3 & 24.1 \\
\hline
\end{tabular}

Tab. 4. $\mathrm{pH}$ values for lime treated samples after 7 days curing period

\begin{tabular}{ccccccc}
\hline Lime content (\%) & $\mathbf{0}$ & $\mathbf{3}$ & $\mathbf{6}$ & $\mathbf{9}$ & $\mathbf{1 2}$ & $\mathbf{1 5}$ \\
\hline $\mathrm{pH}$ & 4.31 & 4.46 & 4.73 & 4.89 & 5.03 & 5.09 \\
\hline
\end{tabular}

test were prepared with different hydrated lime contents and different curing periods. After the removal of the mold, some samples were exposed to air for curing periods of 7, 14, 28, and 90 days while some were initially preserved for the first 7 days in the desiccators and then exposed to air for the rest of the curing period. After all, the unconfined compressive strength tests (UCS) were performed on the treated samples based on ASTM D 2166 - 00 standard.

Figs. 4. a and 4 b show the unconfined compressive strength test results for Talesh Area peat samples treated with different lime contents for 7 and 28 days respectively. In order to compare, the result of the unconfined compressive test on untreated peat soil is illustrated along with the rest of the test results in Figs. 4.a and 4 b. As indicated in the figures, addition of lime to the base peat soil has increased the unconfined compressive strength of the soil. This increase is directly correlated to the lime content and curing period with which the specimens were prepared [14]. Based on the figures, the specimens treated with the lime content of $3 \%$ reached a 28-day compressive strength of $2.59 \mathrm{~kg} / \mathrm{cm}^{2}$, resulting in a strength increase of 652 percent in comparison with the untreated strength of 0.397 while specimens treated with $15 \%$ lime content reached a 28-day strength of 3.44 , surpassing the previously achieved strength and showing a strength increase percentage of 831 .

Fig. 5also shows the effect of curing period on the strength of the lime-treated samples. It can be noticed from the figure that the longer curing period is, the higher the strength of the limetreated samples will be [16]. Accounting for this considerable increase is that the chemical reactions causing the cementation process are slow and gradual in nature and longer curing periods provide adequate time for the process to fully develop. On the other hand, for those 28-day specimens that had been kept in desiccators for the first 7 days of the curing period the results were even higher.

Moreover, the effect of different lime contents on unconfined compressive strength of specimens is shown in Fig. 6. As can be seen in the figure, Regardless of the curing period, the unconfined compressive strength of the lime-stabilized soil increases by the increase of lime content until it reaches a relatively constant value for the specimens prepared with twelve percent of lime content. In fact, passed this point, no dramatic changes will occur to the strength values. Based on this observation, it can be inferred that the optimum lime content for stabilizing the studied soil can approximate to $12 \%$.

Based on the results obtained in the present study and comparing with previous studies, as was mentioned in literature in introduction section (page 1), adding lime to the peat soil has improved it in terms of shear strength and structural characteristics of such soils. In the matter of Unconfined Compressive Strength of the lime-stabilized peat, Said and Taib [14] reported that the UCS of carbide lime-stabilized peat increases by increasing the lime content and curing period, in agreement with what has been obtained in the present study. Another research in this area was conducted by Hebib and Farrel (2003) [12] in which, the effect of adding different additives, including lime, on peat soil was investigated, and similar results to those in this study were indicated.

\subsection{Triaxial compression Test}

For each set of CU triaxial tests, three samples with equal lime contents and curing periods were used for testing under three different confining pressures, providing decent precision for obtaining the Mohr-coulomb strength envelope as a straight line connecting the points of failure on each test Mohr strength circle. This linear strength envelope indicates the strengths at which soil samples under testing fail. The line equation of the envelope yields the values of the soil cohesion (c) and the soil internal friction angle $(\varphi)$ correlating the values of the shear strength and the vertical stress as: $\tau=\sigma \operatorname{tg} \varphi+\mathrm{c}$. In the current study, the untreated soil samples and five groups of lime-treated samples were subjected to CU triaxial compression tests with curing periods of 7 and 28 days, according to BS 1377:1990 [17]. By conducting these triaxial tests, given that triaxial tests are considered as one of the most accurate testing techniques there is in geotechnical studies, it is possible to obtain the shear strength parameters of the stabilized soil, namely the internal angle of friction $\varphi$ and the soil cohesion c. All the tests were performed under three different confining pressures to ensure accuracy of parameters calculations. The results of these tests are shown in Figs. 7fa to 7 f and 8 -a to 8 e for 7-day and 28day specimens, respectively and the corresponding values of the strength parameters of $\mathrm{c}$ and $\varphi$ for each sample are depicted on the respective diagram.

The results obtained from the aforementioned experiments confirm that treating the soil with lime considerably improves the strength of the soil in terms of cohesion, showing an increase 
Tab. 5. Atterberg limits of untreated soil vs. lime treated soil

\begin{tabular}{|c|c|c|c|c|c|}
\hline \multirow{2}{*}{ lime content } & \multirow{2}{*}{ Atterberg limits } & \multirow{2}{*}{ untreated } & \multicolumn{3}{|c|}{ curing period } \\
\hline & & & 1day & 4days & 7days \\
\hline \multirow{3}{*}{$3 \%$} & LL & 66.9 & 47.7 & 46.1 & 44.9 \\
\hline & $\mathrm{PL}$ & 65.8 & 46.9 & 44 & 41 \\
\hline & $\mathrm{PI}$ & - & 0.8 & 2.1 & 3.9 \\
\hline \multirow{3}{*}{$6 \%$} & $\mathrm{LL}$ & 64 & 46.8 & 44.5 & 43.1 \\
\hline & PL & 63.1 & 45.5 & 41.8 & 39.07 \\
\hline & $\mathrm{PI}$ & - & 1.3 & 2.7 & 4.03 \\
\hline \multirow{3}{*}{$9 \%$} & LL & 60.5 & 44.7 & 42.9 & 41.2 \\
\hline & PL & 59.7 & 42.7 & 39.9 & 37 \\
\hline & $\mathrm{PI}$ & - & 2 & 3 & 4.2 \\
\hline \multirow{3}{*}{$12 \%$} & LL & 57.6 & 42.1 & 40.7 & 38.9 \\
\hline & $\mathrm{PL}$ & 56.8 & 39 & 35.5 & 31.2 \\
\hline & $\mathrm{PI}$ & - & 3.1 & 5.2 & 7.7 \\
\hline \multirow{3}{*}{$15 \%$} & LL & 53.9 & 40.2 & 38.1 & 36.5 \\
\hline & PL & 53.7 & 36.2 & 31.6 & 26.4 \\
\hline & $\mathrm{PI}$ & - & 4 & 6.5 & 10.1 \\
\hline
\end{tabular}

NB LL = Liquid Limit, PL= Plastic Limit, PI = Plastic Index

Tab. 6. Back pressure values for CU tests

\begin{tabular}{cccc}
\hline curing period & \multicolumn{2}{c}{ lime content (\%) } & \multicolumn{2}{c}{ back pressure (kPa) } & \multicolumn{2}{c}{ Saturation time (hrs) } \\
& 3 & 150 & 84 \\
\cline { 2 - 4 } 7days & 6 & 150 & 84 \\
\cline { 2 - 4 } & 9 & 200 & 90 \\
\cline { 2 - 4 } & 12 & 200 & 108 \\
\cline { 2 - 4 } & 15 & 250 & 60 \\
\cline { 2 - 4 } & 3 & 100 & 84 \\
\hline
\end{tabular}

in the value of $\mathrm{c}$ from $18 \mathrm{kPa}$ to $101 \mathrm{kPa}$ for the untreated and the sample treated with lime content of $15 \%$, respectively. As can be seen in Figs. 9-a and 9-b for 7-day and 28-day specimens, respectively, the soil cohesion increases as samples tested get prepared and treated with higher lime contents until the value of $9 \%$ of lime content where, according to the graph, the use of higher lime contents ceases to cause a significant increase in the resistance of the treated soil. Hence, the optimum lime content in this case can be considered as $9 \%$.

Based on Figs. 10-a and 10-b for 7-day and 28-day specimens, respectively, in case of the friction angle, unlike the earlier case, it can be seen that by adding lime to the soil, the values of $\varphi$ decrease correspondingly. Accounting for this can be this fact that, since lime particles come between soil particles, the intergranular contact of soil particles due to the distance created by lime particles decreases in soil's structure, causing weaker frictional interactions between the soil grains and therefore resulting in a decrease in the value of the soil friction angle. Moreover, decrease in the value of $\varphi$ is a side effect of the cementation process caused by lime stabilization, rather changing the soil behavior toward the behavior of a cohesive soil with lower values of $\varphi$.

The stress-strain diagrams of triaxial tests have been shown in Figs. 11 and 12 for 7 and 28 day samples, respectively. The legend on each figure indicates the lime content and the curing period by which the specimen was prepared and the confining pressure of CU tests, respectively. For example, 3.28.0.4a represents the test carried out under the confining pressure of $0.4 \mathrm{~kg} / \mathrm{cm}^{2}$ on the specimen with the lime content of 3 percent for stabilization which had been cured and preserved for 28 days. As can be seen from the figures, the peak deviator stress increases by increasing the confining pressure. Also, it can be found from the figures that all of samples showed a fairly dilative behavior.

\subsection{Comparing the results of UCS and CU triaxial tests}

The strength parameters measured in undrained triaxial tests normally differ from those of unconfined compression tests. This difference is specifically more substantial at high consolidation stresses and confining pressures since unconfined compression tests only measure the strength in the condition of zero total confining pressure. In stabilized soils of relatively low strength, the undrained triaxial strength at low effective cell pressures and the strength measured in unconfined compression 


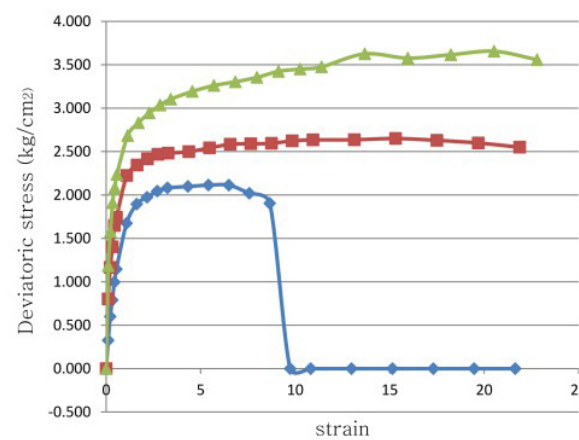

$\rightarrow-3.7 .0 .4 \mathrm{a}$ $=-3.7 .0 .8 \mathrm{a}$ $-3.7 .1 .6 \mathrm{a}$

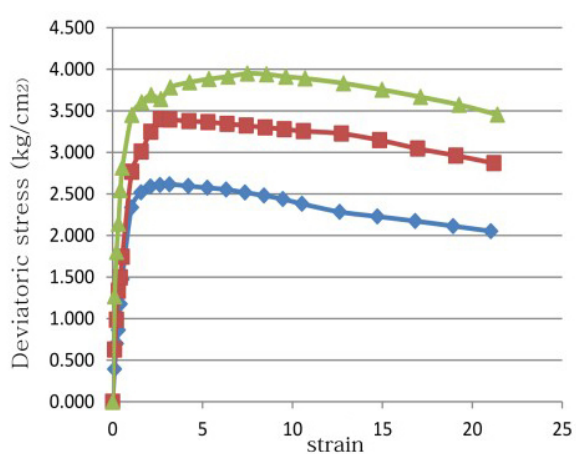

$\rightarrow 6.7 .0 .4 \mathrm{a}$

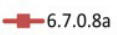

$\rightarrow-6.7 .1 .6 \mathrm{a}$

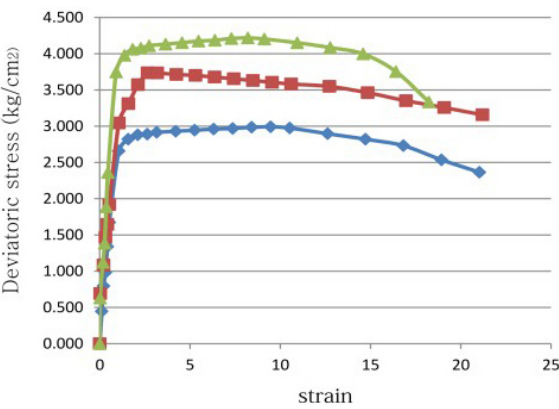

$\rightarrow-9.7 .0 .4 a$

$-9-9.7 .0 .8 \mathrm{a}$

$-9.7 .1 .6 \mathrm{a}$

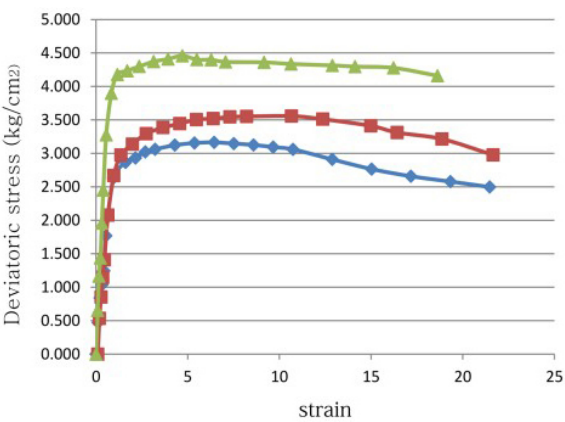

$\rightarrow-12.7 .0 .4 a$

$-12.7 .0 .8 \mathrm{a}$

$-12.7 .1 .6 \mathrm{a}$

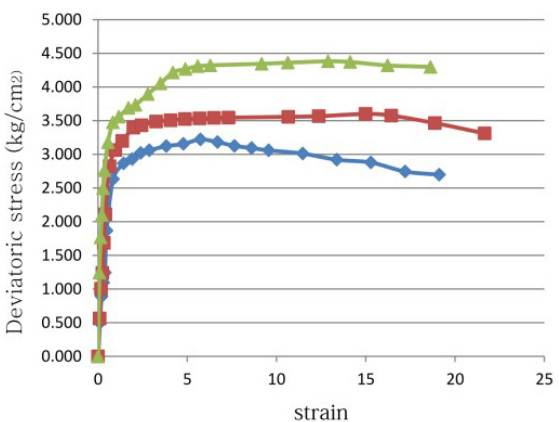

$\rightarrow 15.7 .0 .4 a$

$\rightarrow-15.7 .0 .8 \mathrm{a}$

$\rightarrow 15.7 .1 .6 \mathrm{a}$

Fig. 11. Stress-Strain diagrams for 7-day curing period at different confining pressures
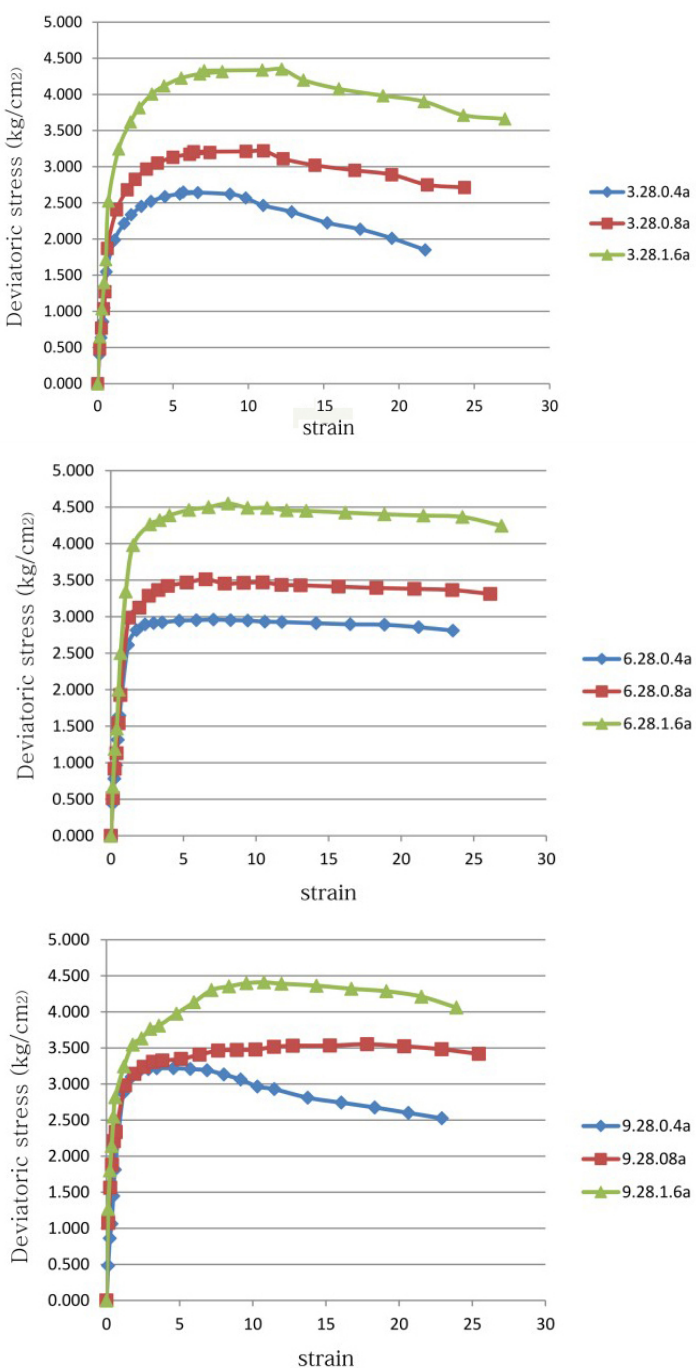

$\rightarrow-9.28 .0 .4 a$

$=-9.28 .08 \mathrm{a}$

$-9.28 .1 .6 \mathrm{a}$

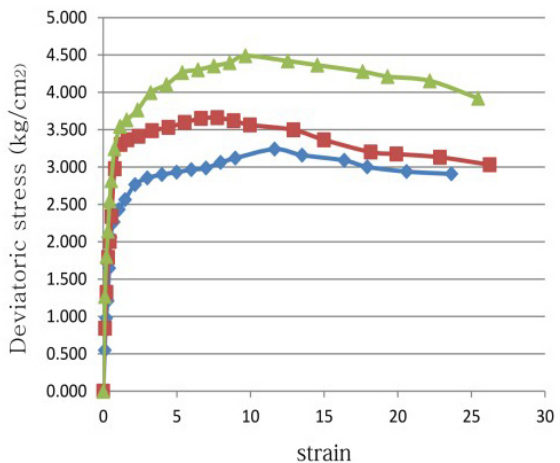

$\rightarrow 12.28 .0 .4 \mathrm{a}$

$-12.28 .0 .8 \mathrm{a}$

$-12.28 .1 .6 \mathrm{a}$

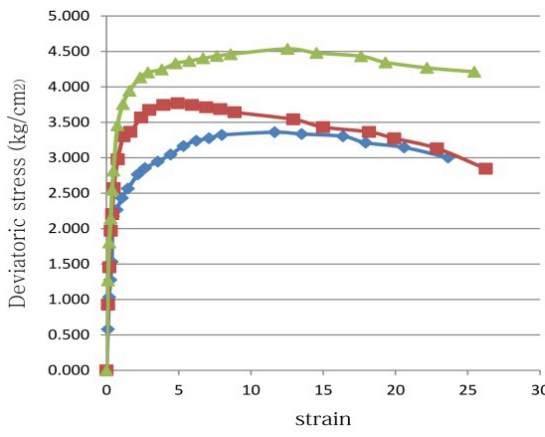

$\neg$-15.28.0.4

$-15.28 .0 .8 \mathrm{a}$

$-15.28 .1 .6 \mathrm{a}$

Fig. 12. Stress-Strain diagrams for 28 -day curing period at different confining pressures 
tests are approximately of the same value in most cases. However, as the strength of the material increases and in low confining pressures, the strength determined by unconfined compression tests in general becomes greater than that determined by undrained triaxial tests.

In order to compare, in the current study, we investigate the difference between the shear strengths obtained in UCS and CU tests for the lime-treated peat samples. Since the two test types are different in nature due to the presence of non-zero confining pressures in the triaxial tests, to ensure similarity in the nature of the two strengths, the equivalent triaxial unconfined strengths of CU tests, namely the strengths in case of zero confining pressure, were estimated by extrapolating the triaxial test results in a way described with an example. For example, as can be seen in Fig. 13, for 28-day treated soil with the lime content of $9 \%$, the equivalent triaxial unconfined strength can be obtained by replacing $x$ with zero in the trend equation, i.e. in the case with zero effective confining stress. In the example above, this yields the equivalent triaxial unconfined strength of triaxial test for the soil treated with the lime content of nine percent equal to 2.645 , a strength value regardless of the confining pressures of 40, 80 and $160 \mathrm{kPa}$ under which CU tests had been carried out. Following the same procedure for all other triaxial tests yields all the other equivalent triaxial unconfined strengths. The differences in unconfined compressive strengths evaluated and the unconfined compression tests and those of CU triaxial tests are shown in Fig. 14 as the "residual" charts. As indicated in the figure, for samples with the curing period of 7 and 28 days, it is obvious that the unconfined compression tests (UCS) yield higher strength values than those equivalent in the triaxial tests.

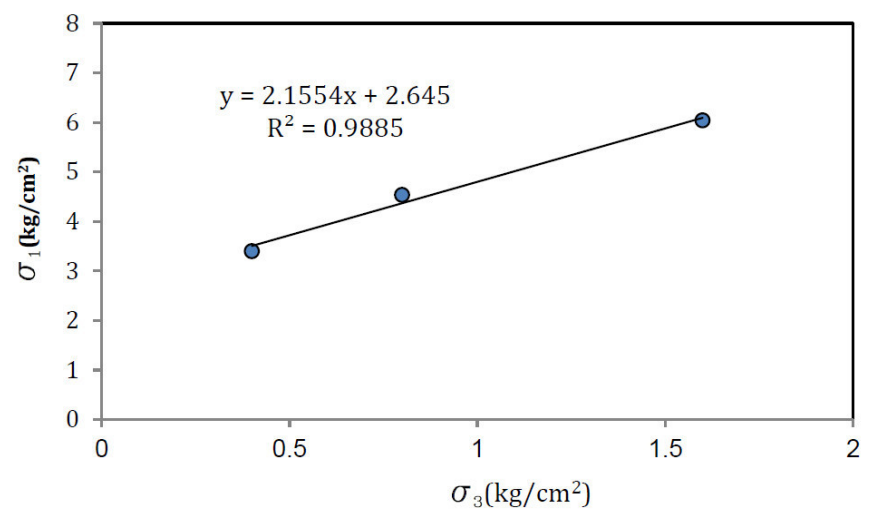

Fig. 13. Example of obtaining the equivalent triaxial unconfined strength

The differences in the values of the two test types can be attributed to several factors. The triaxial tests are conducted on saturated specimens, while the UCS test specimens have lower degrees of saturation, containing the optimum moisture content. In case of 7-day samples, the triaxial and unconfined compression tests were conducted on specimens with different degrees of saturation at different rates of strain. For lower degrees of saturation, as it is the case in the unconfined compression tests, lower pore water pressures are generated and therefore higher strengths are measured since higher generated pore water pres-
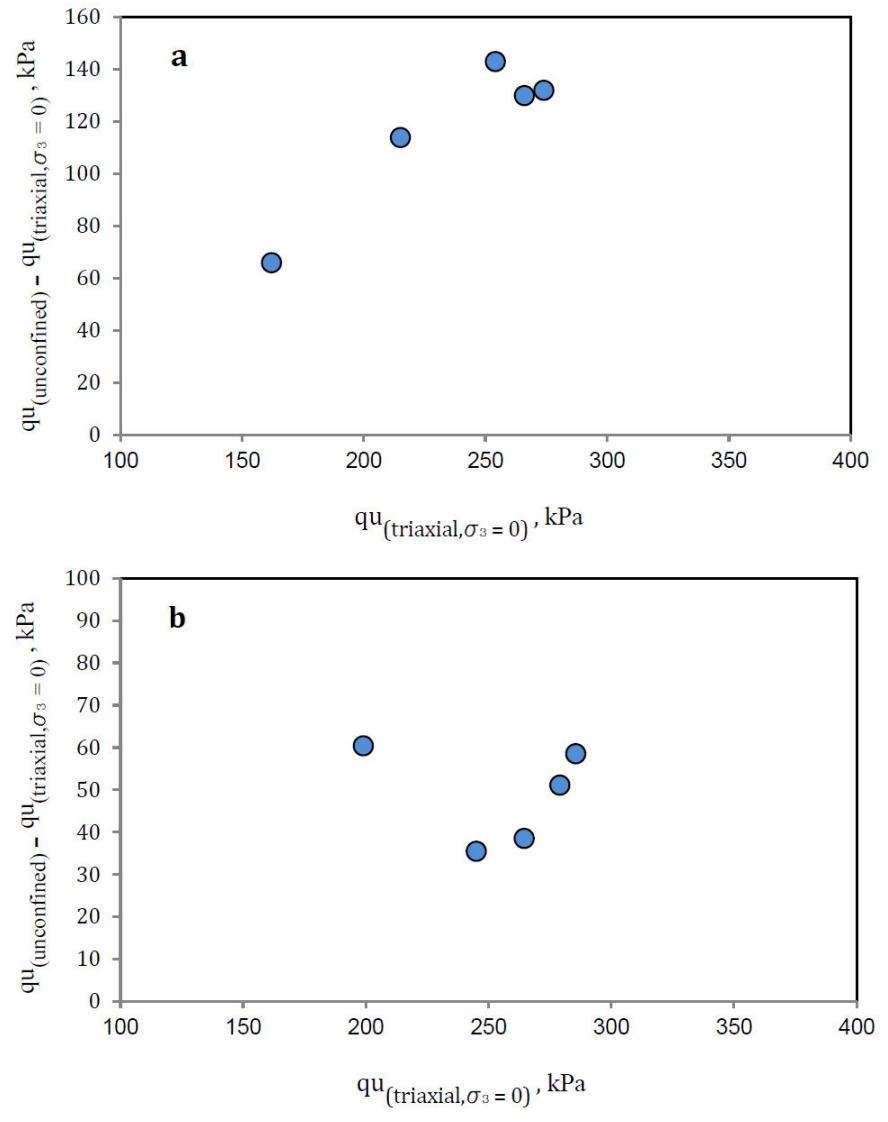

Fig. 14. The residuals (differences between UCS and CU equivalent unconfined strength) a) 7- day cured samples and b) 28- day cured samples.

sures decrease inter-granular interactions and thus lower effective stresses are generated.

Moreover, due to the different strain rates applied during each test type, the results from the two test types are expected to be different since unconfined compression tests are performed considerably faster than triaxial tests, resulting in higher strengths obtained at UCS tests.

In case of 28-day samples, it can be seen that the residuals give lower values than those in 7-day samples. Accounting for this is that the aforementioned factors do not play any significant role since due to the more developed cementation process and the longer curing period, the soil sample is no longer behaving like a porous mass but more like a stiff body in which water is no longer able to move freely and thus pore water pressure is not of great significance and will not affect the strengths measured.

Another comparison between the two methods of UCS and $\mathrm{CU}$ tests can be performed based on the correlation between cohesion (c) and the unconfined compression strength $\left(q_{u}\right)$. The cohesion of the soil (c) is considered to be half of the unconfined compression strength $\left(q_{u}\right)$. The variations of $\mathrm{c}$ with the equivalent triaxial unconfined strengths of $\mathrm{CU}$ tests observed in this study for 7 and 28-days samples are shown in Fig. 15 Based on the results, the value of $\mathrm{c}$ is approximately 0.35 times the equivalent triaxial unconfined strength, estimated from the extrapolation of the results from the triaxial tests. 

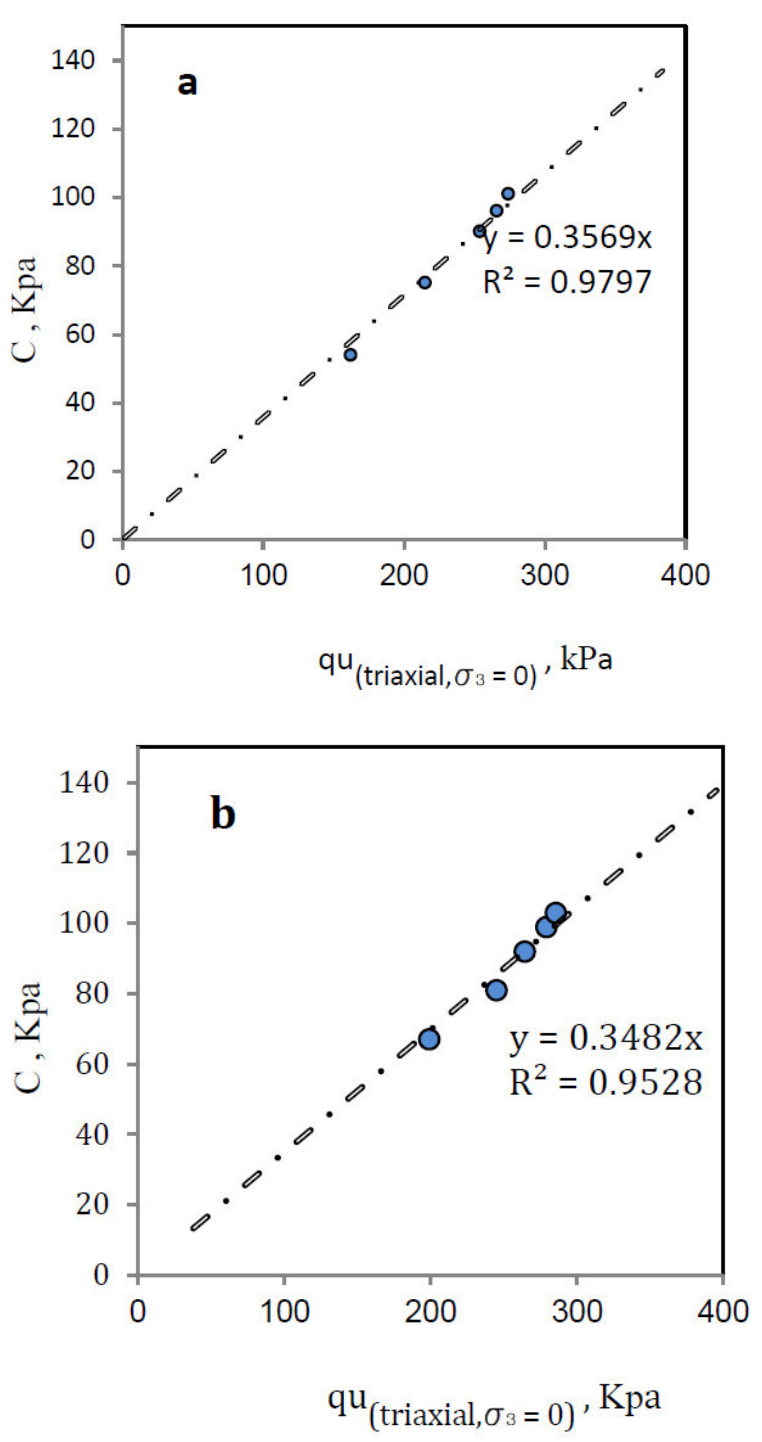

Fig. 15. Determination of correlation between cohesion and equivalent unconfined strength in triaxial test a) 7-days samples b) 28-days samples

\section{Conclusions}

The present study was conducted to investigate and compare the effects of various contents of hydrated lime along with different curing periods on the strength characteristics of peat in consolidated-undrained triaxial (CU) and unconfined compressive strength (UCS) laboratory tests. The UCS and CU tests were performed on specimens with lime contents of 3, 6, 9, 12, and 15 percent and with curing periods of 7, 14, 28, and 90 days. The following results were obtained:

The cementation process caused by the presence of lime in the soil structure along with enough moisture considerably enhances the soil structure in terms of lower porosity values and greater soil strength as a result of the created soil cohesion. While significant increase was observed in the values of cohesion, the internal friction angle values of the peat gradually decreased as a result of the cementation process and weaker inter-granular interactions due to the presence of lime particles in between the soil particles. The optimum lime content for stabilization was reported between 9 and 12 percent of the total weight of samples based on UCS and CU test results. Further comparison between the results of the two test types indicated that while the peat undrained cohesion is half of the unconfined compression strength $\left(\mathrm{q}_{u}\right)$ obtained from UCS tests, the value of the peat undrained cohesion is 0.35 times the equivalent triaxial unconfined strength, namely the strength in case of zero confining pressure estimated by extrapolating the triaxial test results of three confining pressures.

\section{References}

1 Nikookar M, Karimi pashaki M, Arabani M, Engineering properties of stabilized soil of gisoom forest area using cement-sand mixture, Advances in Civil and Environmental Engineering, 2(3), (2014), 162-171.

2 Huat B, Organic and peat soil engineering, University Putra Malaysia; Malaysia, 2004.

3 Hartlen J, Wolski W, Embankments on organic soils, Elsevier; Amsterdam, 1996.

4 Nikookar M, Karimi pashaki M, Nikookar H, Arabani M, The Geotechnical Improvementof Talesh Peat Soil with Cement, 3rd Int. Conf. on New Developments in Soil Mechanics and Geotechnical Engineering, In:; Nicosia, North Cyprus, 2012, pp. 471-477.

5 Wong L, Hashim R, Ali F, Engineering behavior of stabilized peat soil, European J. of Scientific Research, 21(4), (2008), 581-591.

6 Kazemian S, Moayedi $\mathbf{H}$, Mosallanezhad M, The Effect of Cement-Sodium Silicate Grout Compounds on Void Ratio and the Coefficient of Secondary Compression of Treated Fibrous Peat, Journal of Testing and Evaluation, 43(2), (2015), 20140082, DOI 10.1520/JTE20140082

7 Kalantari B, Prasad A, A study of the effect of various curing techniques on the strength of stabilized peat, Transportation Geotechnics, 1(3), (2014), 119-128, DOI 10.1016/j.trgeo.2014.06.002

8 Arabani M, Veis Karami M, A geomechanical properties of lime stabilized clayey sands, The Arabian Journal for Science and Engineering, 1B, (2007), 11-25.

9 Mallela J, Von Quintus H, Smith K, Consideration of lime-stabilized layers in mechanistic-empirical pavement design, The National Lime Association, In:; Arlington, Virginia, 2004.

10 Md Yusof Z, Mohd Harris SN, Mohamed K, Compressive Strength Improvement of Stabilized Peat Soil by Pond Ash - Hydrated Lime Admixture, Applied Mechanics and Materials, 747, (2015), 242-245, DOI 10.4028/www.scientific.net/AMM.747.242

11 Bredenberg H, Holm G, Broms B, Dry-mix method for deep soil stabilization, Proceeding of the international conference, In:; Stockholm, Sweden, 1999.

12 Hebib S, Ferrel ER, Some experiences on the stabilization of Irish peats, Canadian Geotechnical Journal, 40(1), (2003), 107-120, DOI 10.1139/t02091

13 Huat B, Kazemian S, Baraghchi M, A study of the compressibility behavior of peat stabilized by DDM: model and FE analysis, American J. of Phys. Sci, 6(1), (2011), 196-204.

14 Said J, Taib S, Peat stabilization with carbide lime, UNIMAS E-Journal of civil engineering, 1(1), (2009).

15 Shahidul Islam M, Hashim R, Behaviour of stabilised peat: a field study, Scientific Research and Essays, 5(17), (2010), 2366-2374.

16 Nikookar M, Nikookar H, Arabani M, Unconfined compressive strength of lime-stabilized peat, Proceeding of the International Conference 7th SASTech, In:; Bandar-Abbas, Iran, 2013.

17 BS 1377: Methods of test for soils for civil engineering properties, British Standard Institution; London, UK, 1990. 